\title{
Water quality deterioration as a driver for river restoration: a review of case studies from Asia, Europe and North America
}

\author{
Vidhya Chittoor Viswanathan ${ }^{1,2} \cdot$ Mario Schirmer ${ }^{1,2}$
}

Received: 9 January 2015/Accepted: 26 March 2015/Published online: 5 April 2015

(C) Springer-Verlag Berlin Heidelberg 2015

\begin{abstract}
River restoration projects are carried out actively in several countries as an alternative flood protection measure, and also to improve/restore water quality and habitat diversity. The implication of various river restoration measures on water quality is seldom studied. In this review, case studies of restoration projects that aimed at water quality improvement were selected from four industrialized countries in three continents. The water quality concerns and the systematic development of legislative policies towards better water quality management in the different countries considered were assessed. The best management practices for river restoration with respect to water quality amelioration were evaluated with the perspective of the case studies selected. In the various case studies discussed, a combination of different restoration measures were implemented in tandem. The restoration measures were adapted to suit the local conditions and problems. A pre- and post-restoration investigation of the main success indicators was found to be an important criterion for the evaluation of the outcome of restoration projects. Successful restoration projects were found to focus on reduction of pollutant/nutrient input to the rivers, in addition to the implementation of suitable restoration measures. This has been achieved by public infrastructure development (like installation of storm water controls and sewage treatment plants). This review is aimed
\end{abstract}

Mario Schirmer

mario.schirmer@eawag.ch

1 Department of Water Resources and Drinking Water $(\mathrm{W}+\mathrm{T})$, Eawag: Swiss Federal Institute of Aquatic Science and Technology, Überlandstrasse 133, 8600 Dübendorf, Switzerland

2 University of Neuchatel, Centre for Hydrogeology and Geothermics (CHYN), Rue Emile-Argand 11, 2000 Neuchâtel, Switzerland to act as an inventory for future restoration projects with water quality amelioration as their main target.

Keywords River restoration - Water quality - Case studies $\cdot$ Laws and policies - BMPs

\section{Introduction}

Rivers are naturally dynamic; they flood adjacent lands, erode their banks and bed, and move sediment around. Urban development and historical engineering activities can affect this natural balance and result in morphological damage. This can lead to loss of important habitats, cause changes to rates of erosion or sediment deposition and pose an increased risk of flooding elsewhere in the catchment (SEPA 2007). Degraded streams and rivers that drain urban areas are not only characterized by high nutrient loads and concentrations of contaminants, but they also have altered stream morphology and reduced biodiversity (Meyer et al. 2005; Zhou et al. 2012). In recent times, river restoration is globally accepted as an alternative way to protect ecosystem health, preserve water resources and provide flood protection (Palmer et al. 2005; Andrea et al. 2012; Wortley et al. 2013; Kurth and Schirmer 2014). Increased funds are available for restoration projects in various countries through systematic changes in government policies that are now focusing more on river restoration (EU WFD 2000; SEPA 2007). This has resulted in an increase in the number of restoration projects around the world (Wortley et al. 2013; Kurth and Schirmer 2014; Schirmer et al. 2014).

The evaluation of stream corridor restoration is an important step that is often omitted in restoration projects (Kondolf and Micheli 1995; FISRWG 1998).The ability to evaluate the success (or failure) of management schemes 
must rely on data that track a system's response to management. Thus, post-restoration monitoring is necessary to provide valuable information (through 'lessons learned') for the management of restoration projects in the future. It shall also be useful for promoting future restoration projects using previous examples to clearly demonstrate strengths and weaknesses of different scenarios (Palmer et al. 2005; UNEP 2008). In recent literature, there has been reportage of the assessment of the performance of various hydromorphological alterations in the rivers with specific regional context. In Miller and Craig Kochel (2010, 2013), the performance of various in-stream structures has been evaluated across various river basins in North Carolina, USA. Kurth and Schirmer (2014) and González del Tánago et al. (2012) have investigated the merits of the various restoration measures employed in Switzerland and Spain, respectively. However, the effect of the hydromorphological alterations on water quality in rivers (with pre-post-restoration quantitative sampling) have seldom been studied (Bernhardt and Palmer 2011).

This review is aimed at transferring lessons learned from various restoration projects focusing on water quality improvement from different parts of the world. To achieve this, restoration projects aimed at water quality amelioration through river restoration are chosen from four countries across three continents (Europe, Asia and North America).

The manuscript is structured in the following way: In the next section, the overview of the water use in the countries selected, the water quality status and periodic policy changes to improve the condition of the water bodies is discussed. In the following section, various case studies selected are discussed in detail with their main driver, practical methods implemented and their outcomes. In the next following section, the best management practices (BMPs) for water quality amelioration are discussed with the perspective of the case studies chosen. The concluding section includes some recommendations for future restoration projects that target water quality amelioration through river restoration.

\section{Overview of the countries selected-the water use, reasons for deterioration of water quality and chronological development of legislative policies for better water quality management}

Water use varies significantly at a global level. In 2006, the withdrawal was largely for agricultural followed by industrial and municipal sectors. The proportion of water withdrawn varies according to the regional context, as shown in Fig. 1. The water withdrawal per sector varies largely based on the major occupation in the region; it is

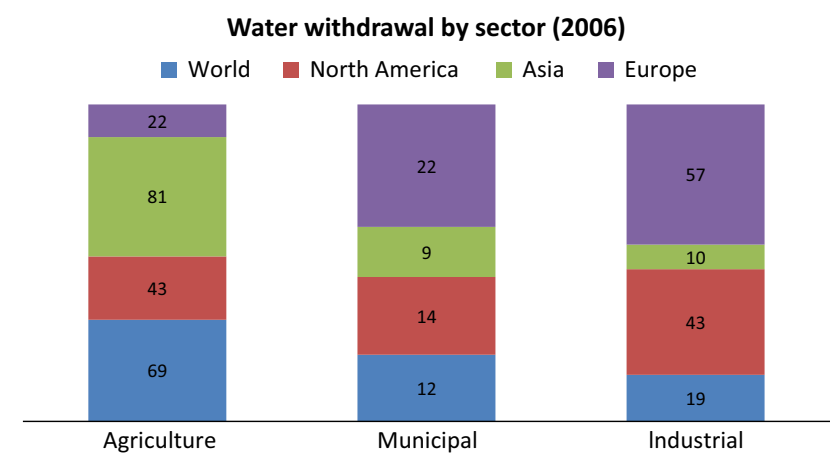

Fig. 1 The water withdrawal by sector globally and in the three continents Asia, Europe and North America is shown. [Data source: FAO AQUASTAT (2012): AQUASTAT database http://www.fao. $\mathrm{org} / \mathrm{nr} / \mathrm{aquastat}]$

withdrawn mainly for agriculture in Asia, for industrial sector in Europe and is equally used for both agricultural and industrial sectors in North America (FAO AQUASTAT 2015).

Some of the features of the countries chosen like country size, amount of internal renewable freshwater (surface + groundwater) available and the water use by sector are tabulated in Table 1. The trend of higher water use for agriculture in Asia and for municipal water use in Europe (Fig. 1) is also reflected in the data from the countries selected (Table 1).

\section{Water quality status of the rivers in the countries selected}

\section{Japan}

Most of the Japanese cities are susceptible to floods because they lie in the lowland, which are below the flood water level of rivers. River engineering has been carried out extensively to protect the rivers from floods. However, water circulation is poor in these channelized rivers. Nitrogen, phosphorus, and other nutrients cause rapid proliferation of algae. The progressive worsening of water quality has led to eutrophication, which causes red tides, which are toxic and harmful to the local fish and other aquatic life (World Bank 2006). River and lake restoration in Japan is extensive and many successes have been documented even in heavily urbanized areas with high population densities (Nakamura et al. 2006).

\section{South Korea}

Apart from an unequal distribution of water resources seasonally and regionally, the rapid industrialization and urbanization since 1960s have polluted many water bodies in South Korea. The major pollution sources that influence 
Table 1 The characteristics of the countries considered, land area, annual average precipitation, amount of internal renewable resources, total and percapita freshwater withdrawal and water use by sector are summarized

\begin{tabular}{|c|c|c|c|c|c|}
\hline $\begin{array}{l}\text { Countries } \\
\text { selected }\end{array}$ & $\begin{array}{l}\text { Land Area } \\
(\times 1000 \text { ha }) \\
\text { (FAO AQUASTAT } \\
\text { 2012) }\end{array}$ & $\begin{array}{l}\text { Average annual } \\
\text { precipitation } \\
\text { (mm/year) } \\
\text { (FAO AQUASTAT } \\
\text { 2012) }\end{array}$ & $\begin{array}{l}\text { Total average } \\
\text { internal renewable } \\
\text { resources }\left(\mathrm{km}^{3} / \text { year) }\right. \\
\text { (FAO AQUASTAT } \\
\text { 2012) }\end{array}$ & $\begin{array}{l}\text { Total freshwater withdrawal } \\
\left(\mathrm{km}^{3} / \text { year)/per capita }\right. \\
\text { consumption }\left(\mathrm{m}^{3} / \text { year }\right) \\
\text { (CIA WORLD FACTBOOK } \\
\text { 2015) }\end{array}$ & $\begin{array}{l}\text { Water use by sector } \\
\text { domestic/industrial/ } \\
\text { agricultural }(\%) \\
\text { (CIA WORLD } \\
\text { FACTBOOK 2015) }\end{array}$ \\
\hline Japan & 37,796 & 1668 & 430 & 90/714 (in 2007) & $20 / 18 / 62$ \\
\hline South Korea & 10,015 & 1274 & 65 & $26 / 549$ (in 2003) & $26 / 12 / 62$ \\
\hline $\begin{array}{l}\text { United Kingdom } \\
\text { (UK) }\end{array}$ & 24,361 & 1220 & 145 & $13 / 213$ (in 2008) & $58 / 33 / 9$ \\
\hline $\begin{array}{l}\text { United States of } \\
\text { America (USA) }\end{array}$ & 983,151 & 715 & 2818 & $478 / 1583$ (in 2005) & $14 / 46 / 40$ \\
\hline
\end{tabular}

the quality of surface waters used for irrigation are wastewater from industries, livestock, sewage and acid mine drainage. This pollution problem continues to grow as both the human and livestock populations steadily increase over the years (FAO 2000).

\section{$U K($ Scotland $)$}

The water quality problems in Scotland are mainly around urban areas, particularly around the populated cities of Glasgow and Edinburgh. Although many large rivers and estuaries, such as the Clyde in the west and the Forth in the east, have seen marked improvements over the last 20 years, water quality problems still remain. Land use in the northeastern part of the river basin district is mainly agricultural, which can give rise to a range of environmental problems (SEPA 2007). Assessments indicate that about $40 \%$ of Scottish waters fail to meet the environmental standards required to support good ecology (SEPA 2007). This is because of the pollution of the water bodies by diffuse agricultural pollution along the east coast, central belt and southwest; the pollution of the urban rivers by sewer overflows and contaminated runoff from roads in the highlands owing to the construction of hydropower dams, and in the lowlands mainly due to urban and agricultural intensification (SEPA 2007).

\section{USA}

During the summers of 2008 and 2009, 1924 river and stream sites across the country were monitored by the US Environmental protection Agency (EPA) under the National Rivers and Streams Assessment 2008-2009 program.

The following water quality assessment was made:

$40 \%$ of the nation's river and stream miles have high levels of phosphorus. $27 \%$ have high levels of nitrogen. Biological communities are at an increased risk when the phosphorus and nitrogen pollution levels are high in the rivers and streams. Phosphorus and nitrogen pollution is caused by the use of excess fertilizers, from wastewater and other sources, and can cause algae blooms, low oxygen levels, and more. A substantial portion of the nation's river and stream miles comprises of poor vegetative cover (24\%) and human disturbances (20\%) near the surface water bodies. These degraded habitat conditions make the rivers and streams more vulnerable to flooding, which in turn contribute to erosion and increased inflow of pollutants into them. In addition to this, the excess levels of streambed sediments, which can affect the habitat of aquatic organisms, were reported in $15 \%$ of the rivers and streams (EPA 2014a).

\section{The history of legislation for water quality improvement in Japan, South Korea, UK (Scotland) and USA}

Many industrialized countries in the world have often gone through a series of legislative reforms over the last 70 years to steer their policies towards being more environment friendly. The legislative time frame among the countries selected has similarities. The policies have changed from focusing on water quality management mainly by pollution prevention, towards adopting an integrated catchment-scale planning approach, with an emphasis on ecological protection as shown in Table 2.

\section{Description of the selected case studies with water quality deterioration as a driver for river restoration}

\section{Cheonggyecheon River, South Korea}

The Cheonggyecheon River in Seoul was originally developed from a brook into 14 waterways by King Taejong in 1412. Following this, the river was covered between 1958-1978 (Fig. 2a). The Cheonggye highway (5.84 km 
Table 2 An overview of some of the legislative changes and policies related to water quality improvement in Japan, South Korea, UK (Scotland) and USA in the chronological order

\begin{tabular}{llll}
\hline Japan (ARRN 2009) & South Korea (ARRN 2009; & United States of America (EPA & UK (Scotland) (SEPA 2007; \\
http://www.evolvingmedia.co.uk, \\
UNDESA 2004)
\end{tabular}

$\begin{aligned} & \text { Water Pollution Control law 1970, River Act 1961, basic principles of } \\ & \text { controls water quality of }\end{aligned}$
river basin management defined freshwater and groundwater

1990, beginning of national census on river environment

Basic environment law 1993, direction for developing measures from the viewpoint of environmental conservation

Amendment to River law 1997, river management such as flood control water use and environment, strong stakeholder engagement encouraged

Law for environmental impact assessment, 1998

Law for Promotion of Natural restoration, 2003

Rules for permitting use of river zones, 2004 (Citizen based planning of rivers for practical use.)

Invasive alien species act and landscape law, 2004, to eradicate certain invasive species

Amendment to Nature oriented river work (beginning of nature oriented river management), 2006
Water Supply and Waterworks Installation Act 1961 and the Sewerage Act 1966, cover water use by industry and households

Management of Drinking Water Act 1965 , addresses issues related to the control of drinking water quality

The Agriculture and Fishery Improvement Act 1997, covers the use of water by agriculture

Water Quality Conservation Act 1990, Ground Water Act 1993, and Dam Construction and Support Act 1999, comprise the general legal and regulatory framework for water resource management and development in South Korea

Water Quality Conservation Act 1997, the government established the Special Comprehensive Measures for Han River Water Quality (1998), followed by River (1999), Geum River (2000), and Yeongsan River (2000)

Creation of eco-friendly river reach in 50 sites, 2005-2011

Establishing comprehensive river management plan (4 major rivers), 2010 similar measures for the Nakdong
Federal Water Pollution Control Act Sewage (Scotland) Act 1968, 1948, first major water pollution law in USA (later amended as Clean Water Act)

Water Quality Act of 1965, States were directed to develop water quality standards establishing water quality goals for interstate waters

National Environmental Policy Act of 1969 (NEPA)

NEPA is the basic national charter for protection of the environment. It establishes policy, sets goals, and provides means for carrying out the policy

Federal Water Pollution Control Act Amendments of 1972, each point source discharger to waters of the U.S. was required to obtain a discharge permit, wastewater standards for industry setup

Safe Drinking Water Act (SDWA) 1974, to protect public health amended twice in 1986 and 1996 to protect drinking water and its sources: rivers, lakes, reservoirs, springs, and ground water wells

The Clean Water Act (CWA) 1977 is an amendment to the Federal Water Pollution Control Act of 1972, which set the basic structure for regulating discharges of pollutants to waters of the United States

Water Quality Act of 1987, development of numeric criteria for those water body segments where toxic pollutants were likely to adversely affect designated uses

1990 National Guidance: Wetlands and Non-Point Source Controldescribes how State non-point source programs can use the protection of existing wetlands and the restoration of previously lost or degraded wetlands to meet the water quality objectives of adjacent or downstream water bodies cottish Water as the water supply and sewerage authority for the whole of Scotland

Water (Scotland) Act 1980

Environment Act 1995, Creation of Scottish Environment Protection Agency

Scotland Act 1998, Water and sewage disposal legislation moved from London to Scottish parliament at Edinburgh

Water Environment and Water Services (Scotland) Act 2003

Water Services (Scotland) Act 2005, separation of Scottish Water's operational and retail functions to promote competition for retail in water supply and sewage disposal services

River Basin Management Plan 2009, environmental management by reduction of diffuse pollution into rivers

Water Environment (controlled activities) regulation 2011, prevent new damage to the water environment from engineering works on rivers (including from maintenance regimes)

European Union's Water Framework Directive (EU WFD 2000) requires incorporation of new

'hydrogeomorphological, chemical and ecological factors' into water quality assessment standards. It states that by 2015 member states must ensure all water bodies reach 'good' ecological status by 2027 

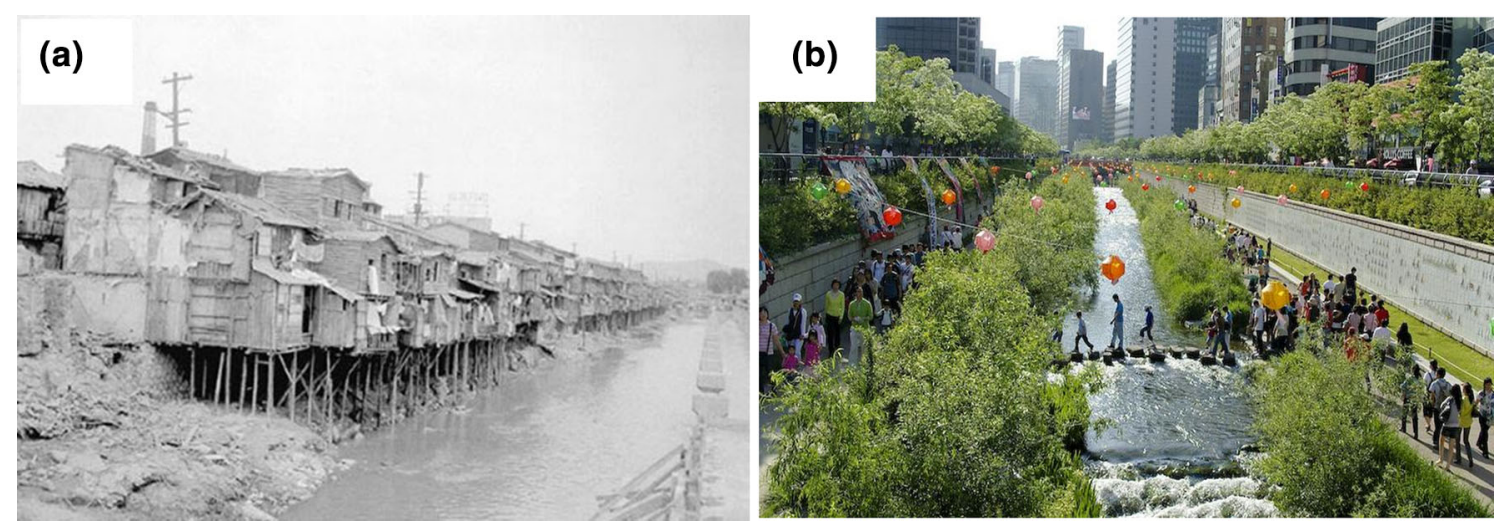

Fig. 2 a Chonggyecheon River in the 1950's. b The river post-restoration in 2008 in downtown Seoul. Source: Wikimedia.org

long) built over this covered river between 1967 and 1976 had been a symbol of Korean development for many years (Hwang 2004).

\section{Drivers}

The elevated highway built over the covered stream was causing air pollution (emission of benzene and nitrous oxide). The population in the Cheonggyecheon area decreased from 66 to $14.9 \%$ in the two decades since the construction of the highway. The covered river was heavily polluted with lack of plant and animal life due to decreased dissolved oxygen (DO) owing to excessive nutrient input (Hwang, 2004).

\section{Solutions}

Demolition of the highway was the first restoration measure. Following the demolition, the urban stream was redesigned from a tributary of the Han River to include flood protection measures with the construction of an embankment to protect the banks from a 200 -year return period of flood (Hwang 2004). Terraces and sidewalks were built in the upper and lower reaches of the stream to make the river accessible to the public. Additionally, intercept sewage lines were also designed in the upper reach to control the inflow of nutrients into the river. Further, a uniform supply of water to maintain a maximum depth of $40 \mathrm{~cm}$ was maintained by redirecting water from the Han River. Jungang sewage treatment plant was upgraded to treat three times the sewage generated in the region; this treated water drains into the river. The opening up of the river and its beautification has resulted in it becoming a serene getaway for the residents of Seoul and tourists alike (Fig. 2b) (Hwang 2004).

\section{Success monitoring}

Monitoring of water quality parameters like DO, biological oxygen demand (BOD), and suspended solids (SS) in the larger Jungnancheon River, which is fed by the (Cheonggycheon River) was carried out pre- and post-restoration. The air quality was measured by nitrous oxide levels and particulate organic matter (POM) in the vicinity of the Cheonggycheon River and the neighbouring regions (Lee and Anderson 2013).

The Cheonggycheon River acts as a ventilation mechanism restoring cool winds. Therefore, a reduction in the air temperature from 30 to $26.6{ }^{\circ} \mathrm{C}$ was achieved in the surrounding areas. The wind-speed in these areas has increased from 2.2 to $7.8 \%$ which explains the temperature reductions (Holzer et al. 2011). Pre-restoration delivery of waste to the river has been replaced by cleaner runoff and recycled water. Therefore a noticeable change in some of the major water quality indicators was observed from 2002 to 2011 , decrease in the SS ( $>16$ to $<10 \mathrm{ppm}$ ), decrease in BOD ( $>12$ to $<5 \mathrm{ppm})$ and increasing levels of $\mathrm{DO}(<4$ to $>6 \mathrm{ppm}$ ) post-restoration has been achieved (Lee and Anderson 2013). There was an increase in the overall biodiversity observed in the river between pre-restoration observation in 2003 and post-restoration in 2008. The diversity of plant species have increased from 62 to 308, fish species from 4 to 25 , insect species from 15 to 192, aquatic invertebrate species from 5 to 53 and bird species from 6 to 36 (Landscape performance 2015).

\section{Izumi River, Japan}

The Izumi River is a small river (9.5 km long), flowing at the bottom of a ravine lying between a plateau in the west side of Yokohama City in the Sakai Rawa River basin (Fig. 3a). The urbanization of the basin has advanced rapidly near the centre of Yokohama. Farmlands occupy middle and lower parts of the basin (ARRN 2009). 
Fig. 3 a The location of the restoration sites along the Izumi River. b Pre-restoration. c Postrestoration of the water side Higashiyama along the Izumi River. Source: Asian River Restoration Network-Modified after ARRN (2009)
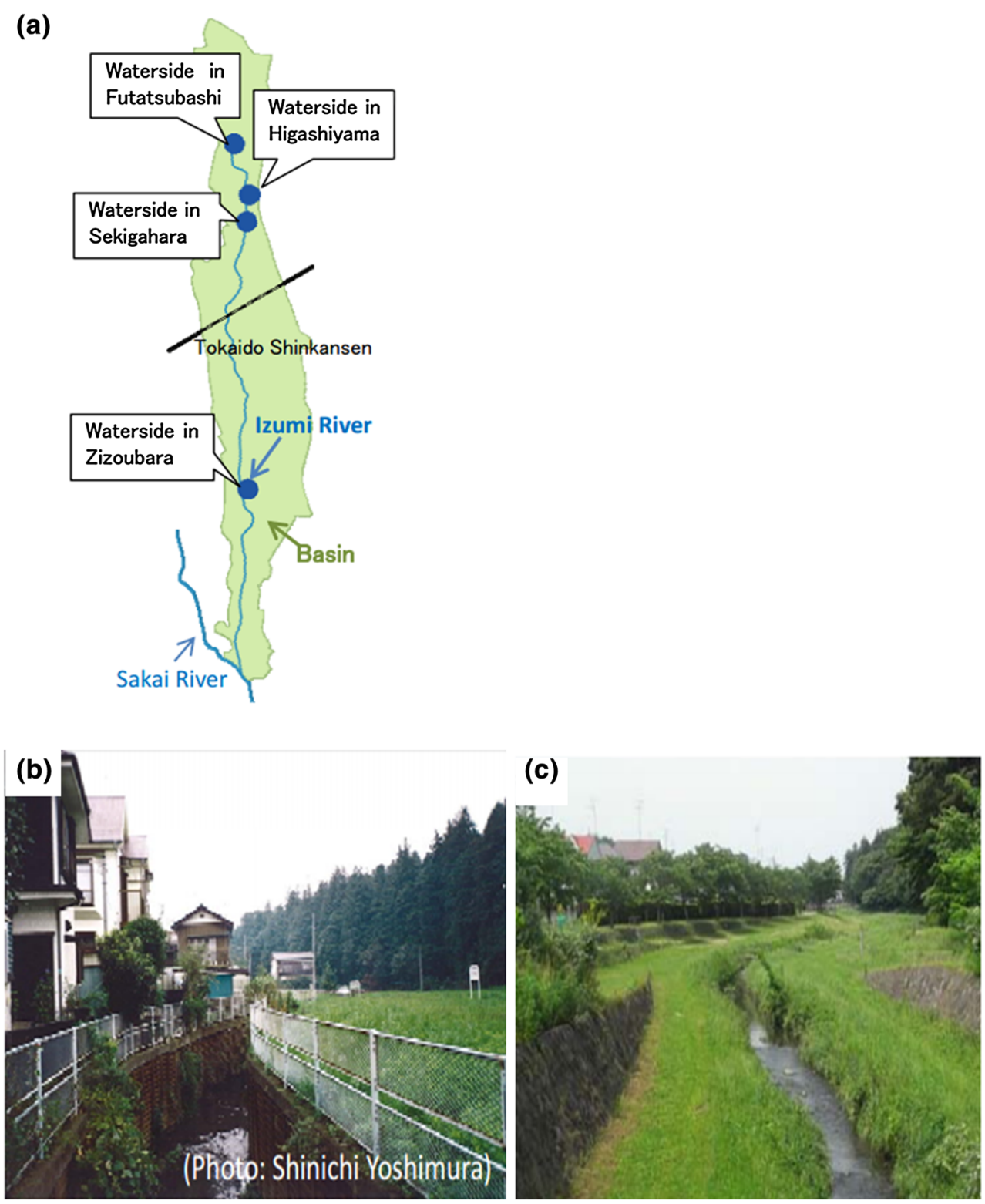

\section{Drivers}

In the 1970s, following a flash flood, there was an urgent need to implement flood control measures. Therefore, the shore of the Izumi River was covered by steel sheet piles and the river bed was dredged, making it hard for the residents to approach the riverside. After the river was altered, the water quality began deteriorating and it was soon called the "Sewage River" (ARRN 2009).

\section{Solutions}

The Izumi River restoration was implemented in several steps. The first step was with the formation of the "Izumi River environmental improvement basic plan", which started in 1987. This involved the local community, particularly the students from the elementary schools in the basin to effectively use the river basin through activities like park and green space conservation. Following this, the implementation of stream reachscale restoration projects was carried out like: "Waterside in Zizoubara" in 1994, "Waterside in Higashiyama" in 1996, "Waterside in Sekigahara" in 1997 and "Waterside in Futatsubashi" in 1998 (Fig. 3). The stream reach-scale restoration measures included reconstruction of the flow paths by widening the river bed and improvement of the river connectivity. Additionally, river bank restoration through slope stabilization and creation of green spaces in the banks were also carried out (ARRN 2009). 


\section{Success monitoring}

There are eight watershed protection agencies located in the watershed, which involve local citizen participation in the clean-up of the river. During a monitoring survey conducted in 2005-2006, it was noted that the water quality of the river had improved significantly, and the BOD decreased from $10 \mathrm{ppm}$ (in 1993) to $<5 \mathrm{ppm}$ (since 1996). Additionally, fish like Carassius and Loach were found in the river for the first time in 1996; these fish had not been found before due to their sensitivity to pollution. 18 species of fish were also found post-restoration in the Izumi River (ARRN 2009).

\section{Ythan River, Scotland}

Ythan River catchment $\left(680 \mathrm{~km}^{2}\right)$ is an agricultural catchment situated in Aberdeenshire, East Scotland. The river has a low flow of around $6 \mathrm{~m}^{3} / \mathrm{s}$. The Ythan River drains into the North Sea. The river channel is flanked by an intertidal area of approximately $2 \mathrm{~km}^{2}$ and the mouth is constricted by a sand bar. Land use in the catchment is dominated by agriculture ( $90 \%$ of the total area), which comprises a mix of arable land and livestock (Balls et al. 1995).

\section{Drivers}

The Ythan catchment was declared the first large-scale Nitrate Vulnerable Zone (in 2000) in Scotland (OSPAR 2006). As the Ythan River, suffered from several water quality issues, that resulted in the eutrophication of the Ythan estuary (a Ramsar wetland and site of special scientific interest), which in turn impacted the waterfowl population in the natural reserve (OSPAR 2006). The Ythan River is the main source of nitrogen to the estuary in the form of total oxidized nitrogen. The concentration of

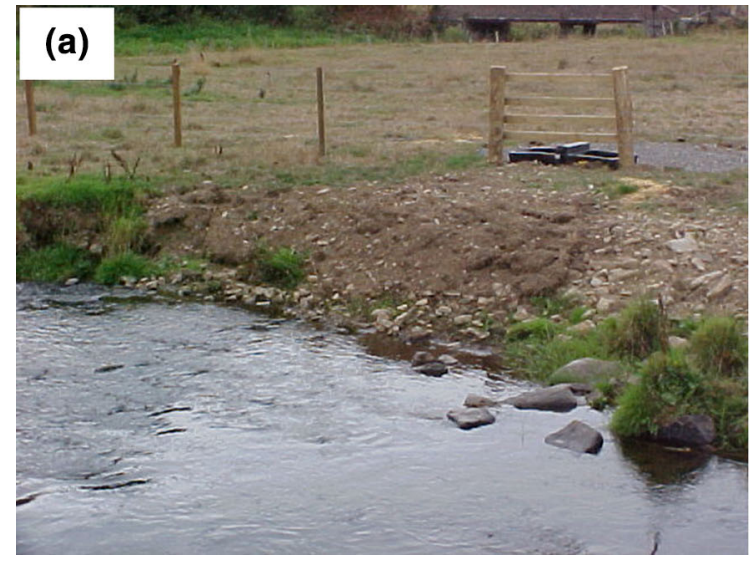

Fig. 4 Fencing and bank restoration at Chapelhaugh near Methlick in the Ythan catchment. The banks had been heavily eroded prerestoration. a Fencing and bank restoration done using felled conifer total oxidized nitrogen in the river increased from ca. $100-150 \mu \mathrm{M}$ in the early 1960 s to ca. $500-550 \mu \mathrm{M}$ in the 1990 s as a result of changing land use patterns in the catchment (OSPAR 2006).

\section{Solutions}

Restoration was carried out at 6 sites along the Ythan River, which were selected by the public from 12 potential sites.

The restoration involved several measures like: removal of non-native overshadowing dense conifer trees from $1.75 \mathrm{~km}$ of the river bank, replanting native trees at 35 sites along the river, creation of buffer strips of $70 \mathrm{~km}$ along the river and its tributaries. In addition to this, creation of nutrient budgeting software and production of nutrient budgets for 62 farms to measure nutrient efficiency in the farms were carried out (Ythan project 2014).

Incentives were given to farmers for the creation of the buffer strips (where no nutrient application was done) close to the river through agri-environment schemes. Flow diversification was accomplished on the Burn of Keithfield (a small stream that joins the Ythan River) in September 2004. Small rocks and boulders were placed at strategic locations to create pools and eddies in the flow that create turbulence effects. These hydrologic features increase the variety of flow patterns in the river, thereby creating a greater habitat variety for insects and fish. Bank stabilization was also carried out using felled conifer trees and native plants that were grown on the banks like in Chapelhaugh near Methlick (Fig. 4) (Ythan project 2014).

\section{Success monitoring}

Eutrophication assessment was carried out between 2001 and 2005 in the Ythan estuary. Additionally, $25 \mathrm{~km}$ of the

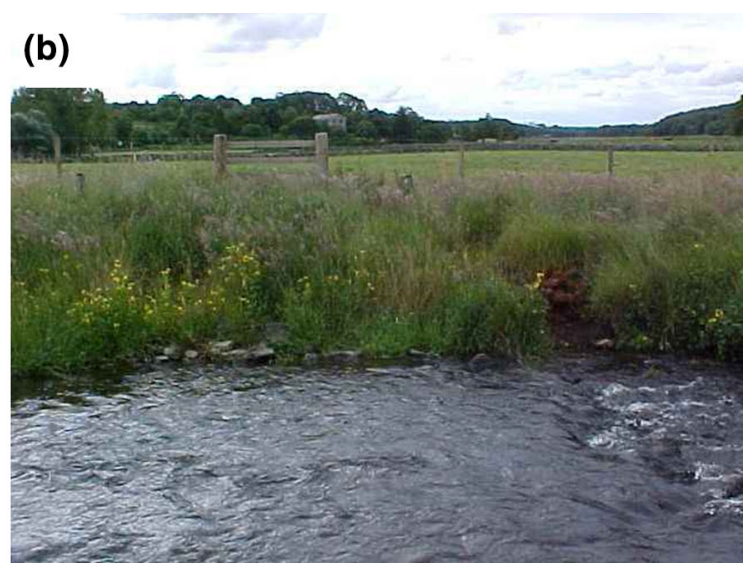

logs. b Regrowth of native vegetation and stabilized banks. Source: Ythan project, retrieved from http://ythan.org.uk on August 42014 
Ythan River was surveyed with the help of local volunteers and 240 samples were collected during the project duration and after the completion of the project (Ythan project 2014).

In the river, the following indicators were considered: $\mathrm{SS}$ - decrease in SS was noted in the buffer strips (created in farmlands, in the vicinity of the river) when compared to the other parts; nitrate-no appreciable difference was noted between the buffer strips and the other monitoring sites; orthophosphate (OP)-decrease in concentration downstream of the buffer strip was observed in a certain section.

In the estuary, the following indicators were considered: Algal cover-there was overall reduction in the algal cover from $31.4 \%$ in 2000 to around $15 \%$ in 2003; Oxidized nitrogen-the oxidized nitrogen did not show any increase from 2000 in the estuary (Dunne 2003); Biodiversitylarge sea trout have been seen upstream, indicating that the fish pass is working as expected. No correlation between the bird count and algal extent was noted (Dunne 2003; Ythan project 2014).

\section{Kissimmee River, Florida, USA}

The lower Kissimmee River is located between Lake Kissimmee and Lake Okeechobee in Florida (Fig. 5). The lower Kissimmee basin has a catchment area of $7804 \mathrm{~km}^{2}$. The regional climate is humid, sub-tropical with an average rainfall of $135 \mathrm{~cm} /$ year (Colangelo 2014; Colangelo and Jones 2005).

\section{Drivers}

In response to prolonged flooding, the $166 \mathrm{~km}$ naturally meandering lower Kissimmee River flowing between Lake Kissimmee and Lake Okeechobee was channelized from 1962 to 1971 into a $90 \mathrm{~km} \mathrm{(1)} \times 100 \mathrm{~m} \mathrm{(b)} \times 9 \mathrm{~m}$ (h) flood control canal called as C-38 (Figs. 5, 6a). The free flowing river was then transformed into a series of impounded reservoirs or pools separated by water control structures (Colangelo and Jones 2005).

The channelization resulted in the elimination of 12,000-14,000 ha of floodplain wetlands leading to the degradation of wild life habitat structure and water quality (Colangelo and Jones 2005; Toth 1993). The new flood control canal eliminated the flow of water into the natural river channel due to its high conveyance capacity, resulting in little or no flow into the natural river channel. In addition to this, the river got disconnected from its floodplain (Colangelo 2014; Colangelo and Jones 2005). The low or no flow in the remnant river channels resulted in vegetation encroachment of floating species like Pistia stratiotes (water lettuce) and Eichhornia crassipes (water hyacinth). This resulted in organic matter accumulation up to $3 \mathrm{~m}$ in the river bed causing eutrophication and consumption of DO in the river, leading to a chronic reduction of DO (Toth 1990). The altered low flow conditions and low DO led to the replacement of local fish like largemouth bass to species tolerant of low DO regimes [such as Lepisosteus platyrahincus (Florida gar) and Amia calva (bowfin)] (Toth 1993). Diverse and abundant wading bird populations declined and were largely replaced by Bubulcus ibis (cattle egret), a species generally associated with upland, terrestrial habitats (Perrin et al. 1982). In addition, there was a high nutrient contribution from the lower Kissimmee River to the Lake Okeechobee, delivering $20 \%$ of total phosphorus (TP) and $31 \%$ of total nitrogen (TN) of the inflow to the lake. Channelization is believed to have facilitated nutrient transport from agricultural watersheds downstream to Lake Okeechobee (Ritter and Flaig 1987).

\section{Solutions}

The Kissimmee River restoration project aims to restore the pre-channelization habitat structure and function of the floodplain ecosystem by including seasonal inflow patterns and improvement of river channel-flood plain connectivity disrupted by channelization.

In the Phase I of restoration (Fig. 5) (completed in 2001), the following measures were done: backfilling was done in the $\mathrm{C}-38$ canal (for $12 \mathrm{~km}$ of the canal), grading the spoil areas to original channel elevations, recarving and reconnecting sections of the river destroyed during channelization. In addition, one water control structure was removed, two new river sections $(2.4 \mathrm{~km})$ were constructed and flow was restored to $24 \mathrm{~km}$ of the natural river channel (Fig. 6b). In this phase, 2344 ha of wetlands were restored (Colangelo and Jones 2005).

In Phase IV a and IV b (Fig. 5) (completed in 2007), $9 \mathrm{~km}$ of the canal was back filled and $8 \mathrm{~km}$ of river channel was recarved. An additional 776 ha of wetlands are expected to be restored owing to these changes (Fig. 6b). Additional Phase II/III stages of restoration are to begin in 2017 to backfill more canal sections, recarve additional river sections and restore more wetlands (Koebel and Bousquin 2014).

In addition to the restoration measures in the Kissimmee River, BMPs in agriculture and Storm Water Treatment Areas (STAs) have been extensively applied to control the inflow of nutrients from the catchment (SFWMD 2015).

\section{Success monitoring}

$D O$ : The pre-restoration monitoring of the lower Kissimmee River was carried out 3 years before phase I of the construction and post-restoration monitoring was done for 8 years after phase $\mathrm{I}$. There was significant recovery of 


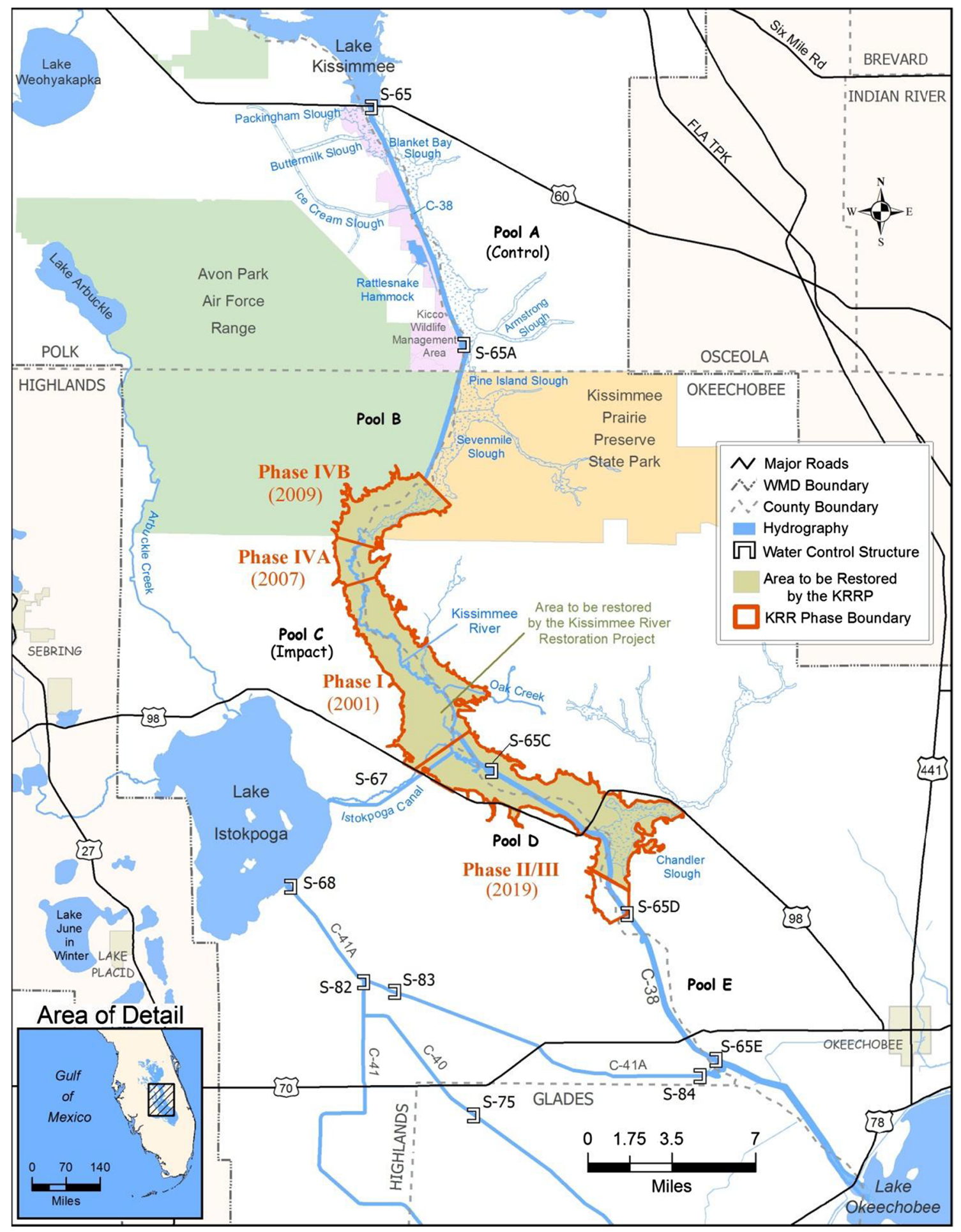

Fig. 5 The extent of the lower Kissimmee River with the various phases of restoration. The various restoration phases (I, 1V A, B, II/ III) are marked along with the year of completion. Source: Modified

mean DO increasing from 2.3 to $4.9 \mathrm{ppm}$ in the impacted areas. The regulated flow and subsequent removal of submergent vegetation in the post-restoration phase after South Florida Environment Report 2015 (Map courtesy: South Florida Water Management District)

resulting in increased re-aeration rates in the river, is attributed to be the reason for the increased DO levels' postrestoration (Colangelo 2014). 


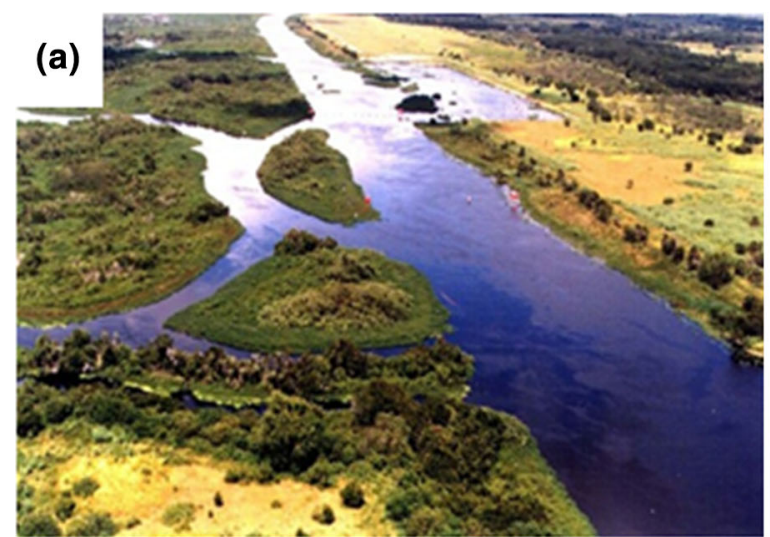

Fig. 6 a The channelized pre-restoration Kissimmee River, C-38 canal in 1995. b Meandering river channel post-restoration (of phases I, IVa and IVb), photo from April, 2014. Source: a U.S. Army Corps

Nutrients: The TP loading post-restoration is expected to be lower, as the channelized C-38 was flushing high nutrient loads and the increased wetland area is expected to have increased nutrient retention. Although total loading in the last 5 years (2007-2011) has been over $50 \%$ lower than loading in the previous 5 years (2002-2006), the reduction cannot be directly attributed to restoration and is dependent on hydrological conditions and land use in the catchment (Jones et al. 2012).

In addition, the BMPs and STAs, have removed more than 4582 metric tons of TP from water entering the Everglades Protection Area. Two decades ago, before STAs were constructed, phosphorus concentrations in Everglades-bound waters averaged 170 parts per billion (ppb). Today, the concentrations in discharges to the Everglades have been as low as $12 \mathrm{ppb}$ (SFWMD 2015).

Fish: In the restored area after Phase I, the relative abundance of invasive fish like bowfin and gar declined from 2004 onwards and reached expected levels in 2010. Fish like centrarchids met the expected levels in 2004-2007 but fell below the $58 \%$ expectation level in 2010 which is attributed to the growth and abundance of other fish as well as to droughts and low flow conditions (Jones et al. 2012).

Birds: After phase I of construction in 2001, the foraging wading birds population began to meet restoration target of $30.6 \mathrm{birds} / \mathrm{km}^{2}$ (3-year running average), except for the drier periods in 2007-2009 and 2009-2011 when this count fell. During 2009-2011, there was a waterfowl abundance exceeding the restoration expectation of 3.9 ducks $/ \mathrm{km}^{2}$ (Jones et al. 2012).

The summary of all the case studies discussed can be found in Table 3.

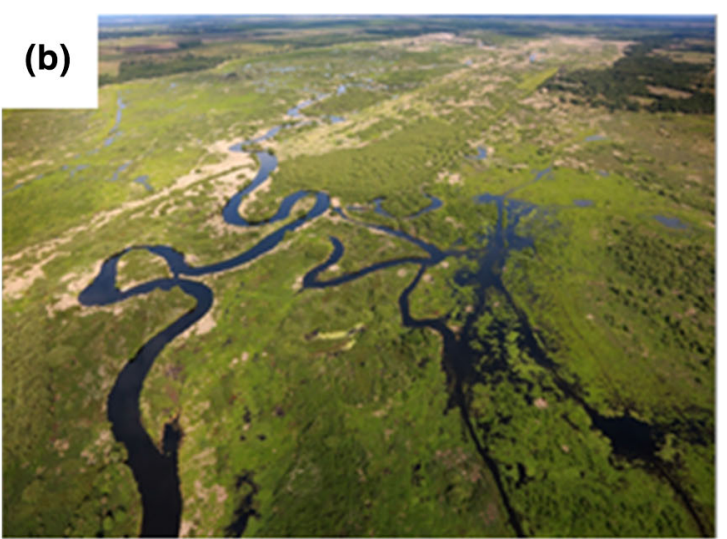

of Engineers Digital Visual Library [Public domain], via Wikimedia Commons. b Photo courtesy: South Florida Water Management District (SFWMD)

\section{Best Management practices (BMPs) for water quality improvement through river restoration}

Restoration of the physical features of a river cannot guarantee a positive effect on the ecological integrity of the system if there are water quality constraints (FISRWG 1998). In Table 4, it is shown that various restoration activities can affect the different water quality stressors simultaneously. While on one hand, the limitation of impervious cover and land disturbing activities reduces the nutrient, toxic and fine sediment runoff from the catchment, thereby increasing the DO in the river. On the other hand, creation of drop structures (created to pass water to a lower elevation, which can control its velocity especially in streams with steep gradients) can result in the decrease of sediment loads along with an increase in the DO in the river.

From the various case studies discussed above, it is clear that a combination of different restoration measures can simultaneously improve the water quality status of the river. Like in the case of the Izumi River, the deterioration of the river water quality was tackled with a combination of restoration measures like widening the river bed and reconstruction of the flow paths, and improvement of the bank stability by growing wood along with creation of green spaces near the stream. This was backed by improvement of sewage treatment facilities in the catchment. These measures not only protect the river from floods but also help improve the water quality by decreasing the BOD in the river. In addition to this, the involvement of the public in the clean-up and monitoring activities only increased the sustainability of the restoration measures.

In the Kissimmee River restoration project, in addition to restoring the flow in the remnant river channels, 


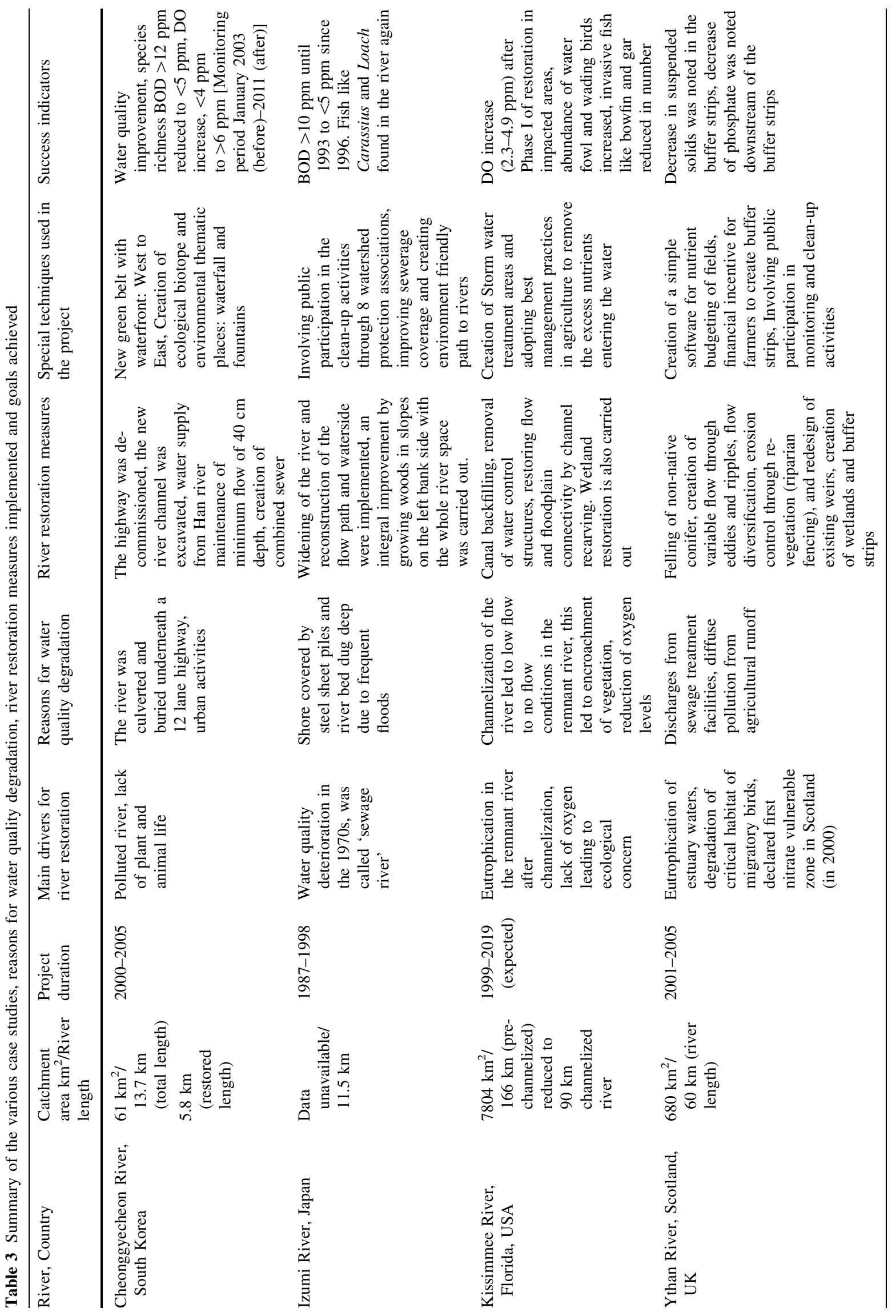


Table 4 The potential water quality impacts of selected stream restoration and catchment best management practices (BMPs) (FISRWG 1998)

\begin{tabular}{|c|c|c|c|c|c|c|c|}
\hline Restoration activities & $\begin{array}{l}\text { Fine sediment } \\
\text { loads }\end{array}$ & $\begin{array}{l}\text { Water } \\
\text { temperature }\end{array}$ & Salinity & $\mathrm{pH}$ & $\begin{array}{l}\text { Dissolved } \\
\text { oxygen (DO) }\end{array}$ & Nutrients & Toxics \\
\hline Reduce land disturbing activities & Decrease & Decrease & Decrease & $\begin{array}{r}\text { Decrease/ } \\
\text { increase }\end{array}$ & Increase & Decrease & Decrease \\
\hline $\begin{array}{l}\text { Limit impervious area in } \\
\text { watershed }\end{array}$ & Decrease & Decrease & $\begin{array}{l}\text { Negligible } \\
\text { effect }\end{array}$ & Increase & Increase & Decrease & Decrease \\
\hline Restore riparian vegetation & Decrease & Decrease & Decrease & Decrease & Increase & Decrease & Decrease \\
\hline Restore wetlands & Decrease & $\begin{array}{r}\text { Decrease/ } \\
\text { increase }\end{array}$ & $\begin{array}{c}\text { Decrease/ } \\
\text { increase }\end{array}$ & $\begin{array}{r}\text { Decrease/ } \\
\text { increase }\end{array}$ & Decrease & Increase & Increase \\
\hline $\begin{array}{l}\text { Stabilize channel and restore } \\
\text { under-cut banks }\end{array}$ & Decrease & Decrease & Decrease & Decrease & Increase & Decrease & $\begin{array}{l}\text { Negligible } \\
\text { effect }\end{array}$ \\
\hline Create drop structures & Increase & $\begin{array}{l}\text { Negligible } \\
\text { effect }\end{array}$ & $\begin{array}{l}\text { Negligible } \\
\text { effect }\end{array}$ & $\begin{array}{r}\text { Decrease/ } \\
\text { increase }\end{array}$ & Increase & $\begin{array}{l}\text { Negligible } \\
\text { effect }\end{array}$ & Decrease \\
\hline Re-establish riffle substrate & $\begin{array}{l}\text { Negligible } \\
\text { effect }\end{array}$ & $\begin{array}{l}\text { Negligible } \\
\text { effect }\end{array}$ & $\begin{array}{l}\text { Negligible } \\
\text { effect }\end{array}$ & $\begin{array}{r}\text { Decrease/ } \\
\text { increase }\end{array}$ & Increase & $\begin{array}{l}\text { Negligible } \\
\text { effect }\end{array}$ & $\begin{array}{l}\text { Negligible } \\
\text { effect }\end{array}$ \\
\hline
\end{tabular}

additional catchment wide measures like creation of STAs and adoption of BMPs in agriculture management have helped reduce the nutrient levels in the river.

In the case of the Ythan River restoration, it was found that the restoration measures like flow diversification by placing boulders in the river were supplemented with community wide actions like creation of buffer strips and nutrient budgets in farms. In this project, there was active public participation in the selection of the sites' pre-restoration and in post-restoration monitoring as well.

Therefore, it is important to consider the local conditions in the catchment and identify the critical parameters that are affected, before choosing the appropriate restoration measures. It is observed that application of morphological alterations in isolation cannot work wonders to rectify the water quality problems in deteriorated streams without fixing the source of the pollutant (like runoff from agriculture, sewage treatment plants), through infrastructural interventions, as emphasized earlier by Bernhardt and Palmer (2011).

\section{Conclusion}

In this paper, an assessment of four river restoration projects that had water quality deterioration as the major driver for river restoration has been done. The projects were chosen from industrialized countries, located in three different continents. Although geographically different, the countries selected have faced similar problems (increased agriculture and urban areas) that have caused water quality deterioration and in turn habitat destruction in their surface water bodies. To address this, the changes to water management policies have evolved with time. They have periodically changed from primarily addressing pollutionrelated problems to a more holistic approach, by adopting integrated river basin management.

In the various case studies considered, the water quality deterioration occurred due to different reasons like narrowing of river bed due to canalization (often as a flood protection measure), rapid urbanization leading to increased sewage discharge and covering the river to develop urban infrastructure like roads and bridges. The improvement of water quality was carried out by adopting a combination of various river restoration measures like widening of the river bed, improvement of stream bank stability with vegetation, creation of wetlands and improving the variability of flow through the creation of pools, riffles and eddies. These restoration measures were often implemented in tandem with engineering alterations to the public infrastructure in the catchment like creating new/upgrading the storm water controls, sewage treatment plants and decommissioning of highways that covered the river.

In successful restoration projects, it is often noted that along with the engineering solutions there was also an emphasis on involving active public participation. These included not only measures like the creation of nutrient budgets for farmers, creation of river fronts and beautification of rivers to improve the public access to the rivers, but also the involvement of the public in the monitoring surveys. The BMPs for river restoration are often carried out in combination as they simultaneously affect more than one parameter. Therefore, it is important to select the appropriate restoration measure in accordance with the local conditions. The success indicators used are often basic water quality parameters like BOD, DO, nutrients and sometimes biological indicators in addition, which are indicative of long-term status recovery. 
Thus, the main points learned from the case studies for water quality amelioration through river restoration are:

(a) Selection of appropriate site specific restoration measures (often in combination) by pre-restoration identification of the critical parameters that are to be rectified.

(b) Involvement of public is encouraged at various phases of the restoration project, in the planning phase as well as in the pre- and post-restoration monitoring phases.

(c) Having a designated post-restoration success monitoring period with specific budget allocation.

(d) Reducing the pollutant source by the creation of buffer strips in agricultural areas and upgradation/ installation of necessary public infrastructure.

The changes to the water management policies in the industrialized nations discussed in this review are also a big factor in the realization of successful restoration projects in these countries. They have achieved this by adopting a holistic approach to river basin management. Additional changes to these policies are desired that lay more emphasis on public participation and promoting catchment wide pollution prevention in tandem with the river reachscale measures.

Acknowledgments This research was completed within the framework of the Marie Curie Initial Training Network ADVOCATE-Advancing sustainable in situ remediation for contaminated land and groundwater, funded by the European Commission, Marie Curie Actions Project No. 265063. Additionally support was provided by the Competence Center Environment and Sustainability (CCES) within the framework of the RECORD and RECORD CATCHMENT projects.

\section{References}

Andrea F, Gschöpf C, Blaschke AP, Weigelhofer G, Reckendorfer W (2012) Ecological niche models for the evaluation of management options in urban floodplain-conservation vs. restoration purposes. Environ Sci. doi:10.1016/j.envsci.2012.08.011

ARRN (2009) Separate volume of "Reference guideline for restoration by eco-compatible approach in River Basin ver. 1" published in March 2009. http://www.a-rr.net/jp/info/letter/ docs/ARRNguideline1-separatevol.pdf. Retrieved on 28.07.2014

Balls PW, MacDonald AM, Pugh KB, Edwards AE (1995) Long-term nutrient enrichment of an estuarine system, Ythan, Scotland (1958-1993). Environ Pollut 90(3):311-321. doi:10.1016/02697491(95)00025-M

Bernhardt ES, Palmer MA (2011) River restoration: the fuzzy logic of repairing reaches to reverse catchment scale degradation. Ecol Appl 21:1926-1931

CIA WORLD FACTBOOK (2015) Central Intelligence Agency, U.S.A, WORLD FACTBOOK. https://www.cia.gov/library/pub lications/the-world-factbook/. Retrieved on 01.03.2015

Colangelo DJ (2014) Interim response of dissolved oxygen to reestablished flow in the Kissimmee River, Florida, U.S.A. Restor Ecol 22:376-387. doi:10.1111/rec.12058
Colangelo DJ, Jones B (2005) Phase I of the Kissimmee River restoration project, Florida, USA: impacts of construction on water quality. Environ Monit Assess 102:139-158. doi:10.1007/ s10661-005-6017-3

Dunne B (2003) The relationship between algal mats and wading bird populations in the Ythan estuary, North east Scotland, M.Sc. Thesis, Aberdeen University

EPA (2014a) National Rivers and Streams Assessment, 2008-2009. A collaborative survey draft. http://water.epa.gov/type/rsl/monitor ing/riverssurvey/upload/NRSA0809_Report_Final_508Compliant_ 130228.pdf. Retrieved on 30.07.2014

EPA (2014b) Policy \& GuidancelLaws \& RegulationsIUS EPA. [online]. http://www2.epa.gov/laws-regulations/policy-guidance. Accessed 30 July 2014

EU WFD (2000) European Commission: Directive 2000/60/EC of the European Parliament and of the Council establishing a framework for Community action in the field of water policy ("Water Framework Directive"). J Eur Community 327(1):1-72

FAO (2000) Food and Agricultural organization. Water Quality Management and Control of Water Pollution. Proceedings of a Regional Workshop, Bangkok, Thailand, 26-30 October 1999, ISBN 92-5-104503-8.ftp://ftp.fao.org/agl/aglw/docs/wr21.pdf. Retrieved on 28.07.2014

FAO AQUASTAT (2012) Food and agricultural organization. AQUASTAT database. http://www.fao.org/nr/water/aquastat/glo balmaps/AquastatWorldDataEng_20121214_Withdrawal.pdf. Retrieved on 9.03.2015

FAO AQUASTAT (2015) Food and agricultural organization, AQUASTAT. http://www.fao.org/nr/water/aquastat/water_use/ index.stm. Retrieved on 9.03.2015

FISRWG (1998) Stream corridor restoration: principles, processes and practices. Federal Inter-Agency Stream Restoration Working Group (FISRWG),GPO Item No. 0120-A. USDA, Washington, DC. ISBN 0-934213-59-3. http://npscolorado.com/category/ stream-restoration-bmp/. Retrieved on 30.07.2014

González del Tánago M, García de Jalón D, Román M (2012) River restoration in Spain: theoretical and practical approach in the context of the european water framework directive. Environ Manag 50:123-139. doi:10.1007/s00267-012-9862-1

Holzer M, Kong D, Bromberg D (2011) Citizen participation: innovative and alternative modes for engaging citizens cases from the United States and South Korea. Published by the American Society for Public Administration (ASPA) and the National Center for Public Performance (NCPP) at the School of Public Affairs and Administration (SPAA), Rutgers UniversityNewark. ISBN 978-0-942942-13-2

Hwang K (2004) PhD thesis: Restoring Cheonggyecheon Stream in the Downtown Seoul, Seoul development institute, Seoul

Jones LB, Anderson DH, Bousquin SG, Carlson C, Cheek DM et al (2012) Kissimmee River Restoration and Basin Initiatives. In: South Florida Environmental Report 2012. South Florida Water Management District, South Florida, U.S.A

Koebel JW, Bousquin SG (2014) The Kissimmee River restoration project and evaluation program, Florida, U.S.A. Restor Ecol 22:345-352. doi:10.1111/rec.12063

Kondolf GM, Micheli ER (1995) Evaluating stream restoration projects. Environ Manag 19(1):1-15. doi:10.1007/BF02471999

Kurth A-M, Schirmer M (2014) Thirty years of river restoration in Switzerland: implemented measures and lessons learned. Environ Earth Sci 72(6):2065-2079. doi:10.1007/s12665-014-3115-y

Landscape performance (2015) Cheonggyecheon Stream Restoration Project. http://landscapeperformance.org/case-study-briefs/cheong gyecheon-stream-restoration. Retrieved on 11.03.2015

Lee JY, Anderson CD (2013) The restored Cheonggyecheon and the quality of life in Seoul. J Urban Technol 20:3-22. doi:10.1080/ 10630732.2013.855511 
Meyer JL, Paul MJ, Taulbee WK (2005) Stream ecosystem function in urbanizing landscapes. J N Am Benthol Soc 24(3):602-612. doi:10.1899/04-021.1

Miller J, Craig Kochel R (2010) Assessment of channel dynamics, instream structures and post-project channel adjustments in North Carolina and its implications to effective stream restoration. Environ Earth Sci 59(8):1681-1692. doi:10.1007/s12665-0090150-1

Miller J, Craig Kochel R (2013) Use and performance of in-stream structures for river restoration: a case study from North Carolina. Environ Earth Sci 68:1563-1574. doi:10.1007/s12665-012$1850-5$

Nakamura K, Tockner K, Amano K (2006) River and wetland restoration: lessons from Japan. Bioscience 56(5):419-429. doi:10.1641/0006-3568(2006)056[0419:RAWRLF]2.0.CO

OSPAR (2006) The Convention for the protection of the marine Environment of the North-East Atlantic. Eutrophication Assessment Reports-Estuary Ythan. http://www.cefas.defra.gov.uk/ publications-and-data/scientific-series/ospar-eutrophication-asse ssments/scotland-reports.aspx. Retrieved on 04.08.2014

Palmer MA, Bernhadt ES, Allan JD et al (2005) Standards for ecologically successful river restoration. J Appl Ecol 42:208-217. doi:10.1111/j.1365-2664.2005.01004.x

Perrin LS, Allen MJ, Rowse LA, Montalbano F III, Foote KJ, Olinde MW (1982) A report on Fish and Wildlife Studies in the Kissimmee River Basin and Recommendations for Restoration. Florida Game and Freshwater Fish Commission, Okeechobee, Florida

Ritter G, Flaig EG (1987) 1986 Annual report-rural clean water program. Technical memorandum. South Florida Water Management district, West Palm Beach

Schirmer M, Luster J, Linde $\mathrm{N}$ et al (2014) Morphological, hydrological, biogeochemical and ecological changes and challenges in river restoration-the Thur River case study. Hydrol Earth Syst Sci 18:2449-2462. doi:10.5194/hess-18-2449-2014

SEPA (2007) Scottish Environment Protection Agency: Significant management issues in the Scotland river basin district. http:// www.sepa.org.uk/water/water_publications/swmi.aspx. Retrieved on 29.07.2014

SFWMD (2015) South Florida Water Management District. http://my. sfwmd.gov/portal/page/portal/xweb\%20protecting\%20and\%20res toring/water\%20quality\%20stormwater\%20treatment\%20areas. Retrieved on 11.03.2015

Toth LA (1990) Impacts of channelization on the Kissimmee River ecosystem. In: Loftin K, Toth L, Obeysekera J (eds) Proceedings of the Kissimmee River Restoration Symposium. South Florida Water Management District, West Palm Beach, pp 47-56

Toth LA (1993) The ecological basis of the Kissimmee River restoration plan. Fla Sci 56:25-51

UNDESA (2004) UN Department of Economic and Social Affairs: Sustainable development knowledge platform, Country profiles, Republic of Korea, Freshwater 2004. http://www.un.org/esa/ agenda21/natlinfo/countr/repkorea/waterKorea04f.pdf. Retrieved on 28.07.2014

UNEP (2008) Water Quality for Ecosystem and Human Health, 2nd edn. ISBN 92-95039-51-7-Prepared and published by the United Nations Environment Programme Global Environment Monitoring System (GEMS)/Water Programme

World Bank (2006) Water Resources Management in Japan Policy, Institutional and Legal Issues, World Bank Analytical and Advisory Assistance (AAA) Program. http://siteresources.world bank.org/INTEAPREGTOPENVIRONMENT/Resources/WRM_ Japan_experience_EN.pdf. Retrieved on 28.07.2014

Wortley L, Hero J-M, Howes M (2013) Evaluating ecological restoration success: a review of the literature. Restor Ecol 21(5):537-543. doi:10.1111/rec.12028

Ythan Project (2014) The Ythan Project. [online]. http://www.ythan. org.uk/. Accessed 4 Aug 2014

Zhou T, Wu J, Peng S (2012) Assessing the effects of landscape pattern on river water quality at multiple scales: a case study of the Dongjiang River watershed, China. Ecol Indic 23:166-175. doi:10.1016/j.ecolind.2012.03.013 